\title{
PERSEPSI CIVITAS AKADEMIKA TENTANG PERILAKU KEPEMIMPINAN KETUA - KETUA JURUSAN DI LINGKUNGAN FAKULTAS TARBIYAH DAN ILMU KEGURUAN INSTITUT AGAMA ISLAM NEGERI PADANGSIDIMPUAN
}

\author{
ZULHIMMA \\ Dekan dan Dosen Fakultas Tarbiyah dan Ilmu Keguruan IAIN Padangsidimpuan \\ Email: zulhimma2211@gmail.com
}

\begin{abstract}
This research is about "Persepsi Civitas Akademika tentang Perilaku Kepemimpinan Ketua-ketua Jurusan di Lingkungan Fakultas Tarbiyah dan Ilmu Keguruan Institut Agama Islam Negeri Padangsidimpuan". The problems are about the perception of the lecturers, students, and all officers to the Leaders of all Study Program in Tarbiyah and Teacher Training Faculty of IAIN Padangsidimpuan. This research has been done by using descriptive qualitative research with interviews, observation, and questionnaires as the instruments of the research. The result of the research showed that all civitas academics of IAIN Padangsidimpuan in Tarbiyah and Teacher Training Faculty felt that all of the leaders had good attitude leadership.
\end{abstract}

Keywords: perception, attitude, leadership, civitas academics.

\begin{abstract}
Abstrak
Penelitian ini berjudul "Persepsi Civitas Akademika tentang Perilaku Kepemimpinan Ketua-ketua Jurusan di Lingkungan Fakultas Tarbiyah dan Ilmu Keguruan Institut Agama Islam Negeri Padangsidimpuan". Adapun masalah dalam penelitian ini adalah 1) Bagaimanakah persepsi dosen tentang perilaku kepemimpinan Ketua-ketua Jurusan di Lingkungan Fakultas Tarbiyah dan Ilmu Keguruan IAIN Padangsidimpuan? 2) Bagaimanakah persepsi mahasiswa tentang perilaku kepemimpinan Ketua-ketua Jurusan di Lingkungan Fakultas Tarbiyah dan Ilmu Keguruan IAIN Padangsidimpuan? 3) Bagaimanakah persepsi pegawai tentang perilaku kepemimpinan Ketua-ketua Jurusan di Lingkungan Fakultas Tarbiyah dan Ilmu Keguruan IAIN Padangsidimpuan? Penelitian ini menggunakan metode deskriptif kualitatif, dengan menggunakan instrumen pengumpulan data melalui wawancara, observasi, dan angket. Adapun hasil penelitian ini adalah bahwasanya persepsi civitas akademika, baik dosen, mahasiswa maupun pegawai terhadap perilaku kepemimpinan Ketua-ketua Jurusan di Lingkungan Fakultas Tarbiyah dan Ilmu Keguruan IAIN Padangsidimpuan adalah baik.
\end{abstract}

Kata Kunci: persepsi, perilaku, kepemimpinan, civitas akademika. 
36 | TAZKIR: Jurnal Penelitian Ilmu-ilmu Sosial dan Keislaman

Vol.02 No. 2 Desember 2016

\section{PENDAHULUAN}

Gaya kepemimpinan sangat mempengaruhi kinerja bawahan. Para pegawai memiliki pandangan tersendiri terhadap cara-cara yang di tempuh seorang pemimpin dalam menjalankan tugasnya .Pandangan bawahan terhadap kepemimpinan atasan merupakan hasil dari apa yang dilakukan pemimpin terhadap bawahannya di dalam menjalankan kepemimpinannya. Kepemimpinan merupakan seni dan ketrampilan seseorang dalam memanfaatkan kekuasaannya untuk mempengaruhi orang lain agar melaksanakan aktivitas tertentu yang diarahkan pada tujuan tertentu, dengan demikian pemimpin adalah motivator, stabilisator, katalisator, creator dan dinamisator organisasi.

Ketua - Ketua Jurusan merupakan pemimpin ditingkat jurusan. Mereka menaungi dosen - dosen, pegawai dan mahasiswa di tingkat jurusan masing masing. Penyelenggaraan fungsi IAIN Padangsidimpuan sebagai lembaga pendidikan Agama Islam Negeri bertujuan untuk menyiapkan peserta didik menjadi anggota masyarakat yang memiliki kemampuan akademik atau professional yang beriman, bertakwa serta berakhlak mulia dan dapat menerapkan, mengembangkan dan/atau menciptakan ilmu pengetahuan keislaman, teknologi yang berlandaskan ajaran Islam, dan mengembangkan dan menyebarluaskan ilmu pengetahuan keislaman, tehnologi dan seni yang berlandaskan ajaran Islam.

Persepsi bawahan terhadap perilaku kepemimpinan akan mempengaruhi kinerja mereka, termasuk persepsi civitas akademika kampus terhadap kepemimpinan ketua - ketua jurusan di lingkungan Fakultas Tarbiyah dan Ilmu Keguruan IAIN Padangsidimpuan, yang dimaksud adalah persepsi civitas akademika tentang perilaku kepemimpinan ketua - ketua jurusan adalah pandangan Dosen, pegawai dan Mahasiswa terhadap kecakapan Ketua Jurusan Pendidikan Agama, Tadris / Pendidikan Matematika, Tadris / Pendidikan Bahasa Inggris dan Pendidikan Bahasa Arab dalam mempengaruhi orang lain agar melakukan sesuatu sesuai dengan tujuan yang ingin dicapai

Adapun rumusan masalah dalam penelitian ini adalah:

1. Bagaimanakah persepsi dosen tentang perilaku kepemimpinan ketua- ketua Jurusan di Lingkungan Fakultas Tarbiyah dan Ilmu Keguruan IAIN Padangsidimpuan? 
2. Bagaimanakah persepsi mahasiswa tentang perilaku kepemimpinan ketua ketua Jurusan di Lingkungan Fakultas Tarbiyah dan Ilmu Keguruan IAIN Padangsidimpuan?

3. Bagaimanakah persepsi pegawai tentang perilaku kepemimpinan ketuaketua Jurusan di Lingkungan Fakultas Tarbiyah dan Ilmu Keguruan IAIN Padangsidimpuan?

\section{TINJAUAN PUSTAKA}

Civitas Akademika adalah masyarakat akademik yang ada di dalam sebuah perguruan tinggi, disebut juga masyarakat kampus, yaitu dosen, mahasiswa dan pegawai. Dosen merupakan salah satu anggota dari Civitas Akademika. Dosen, memiliki posisi yang sangat menentukan keberhasilan pendidikan, karena fungsi utama dosen adalah merancang, mengelola, melaksanakan dan mengevaluasi perkuliahan. Salah satu faktor yang mempengaruhi Dosen adalah kinerjanya didalam merencanakan / merancang, melaksanakan dan mengevaluasi proses pembelajaran. Dosen adalah pendidik profesional dan ilmuwan dengan tugas utama mentransformasikan, mengembangkan, dan menyebarluaskan ilmu pengetahuan, tehnologi melalui pendidikan, penelitian dan pengabdian kepada masyarakat.

Dalam kegiatan akademik, keberadaan mahasiswa juga menentukan mutu suatu lembaga pendidikan. Mahasiswa merupakan anggota civitas akademika di perguruan tinggi. Dalam Undang - Undang Republik Indonesia Nomor 12 Tahun 2012 tentang pendidikan tinggi dalam pasal 13 ayat 1 disebutkan bahwa mahasiswa sebagai anggota civitas akademika diposisikan sebagai insan dewasa yang memiliki kesadaran sendiri dalam mengembangkan potensi diri di perguruan tinggi untuk menjadi intelektual, ilmuan, praktisi, dan/ atau profesional. ${ }^{1}$ Mahasiswa mempunyai harapan besar untuk menjadi seorang sarjana ketika mereka telah menyelesaikan studinya di tingkat perguruan tinggi. Mahasiswan harus menyadari dan mempersiapkan diri sejak awal agar menjadi sarjana yang menjadi harapan nusa dan bangsa.

Dalam kegiatan suatu pergurun tinggi unsur manusia merupakan unsur penting, sebab kelancaran jalannya pelaksanaan program perguruan tinggi sangat ditentukan oleh manusia - manusia yang mnejalankannya.Peranan

\footnotetext{
${ }^{1}$ Sekolah Tinggi Agama Islam Negeri Padangsidimpuan. Standar Mutu Mahasiswa , ( Padangsidimpuan: STAIN Psp, 2013), hlm.5
} 
38 | TAZKIR: Jurnal Penelitian Ilmu-ilmu Sosial dan Keislaman

Vol.02 No. 2 Desember 2016

pegawai cukup besar dalam melancarkan roda administrasi di sebuah perguruan tinggi. Pegawai melaksanakan tugas - tugas keadministrasian yang berhubungan dengan tata persuratan. "Pegawai dalam menjalankan pekerjaannya tidak sekedar hanya sebagai pengikut dari apa yang diinstruksikan pemimpin, melainkan juga penentu keberhasilan suatu lembaga dalam mencapai tujuan organisasi. ${ }^{2}$ Dalam melaksanakan kerjanya, pegawai harus mempunyai komitmen, suatu tindakan, dedikasi, dan kesetiaan seseorang pada janji yang telah dinyatakannya untuk memenuhi tujuan organisasi dan individunya.

H.M. Daryanto menyatakan pemimpin adalah seorang yang memiliki kecakapan tertentu yang dapat mempengaruhi para pengikutnya untuk melakukan kerja sama ke arah pencapaian tujuan yang telah ditetapkan. ${ }^{3}$ Dalam konteks organisasi, pemimpin berkaitan dengan proses merencanakan, mengorganisasi, menggerakkan, mengarahkan, mengendalikan, mengontrol, mengawasi dan mengevaluasi program dana kegiatan yang berkitan dengannkemajuan lembaga pendidikan. ${ }^{4}$

Perilaku kepemimpinan terfokus terhadap fungsi kepemimpinan dan gaya kepemimpinan seorang pemimpin menjalankan kepemimpinannya dengan berbagai perilaku yang didorong untuk mencapai tujuan sesuai dengan tugas dan tanggung jawabnya sebagai pemimpin organisasi tertentu. Disisi lain perilaku dalam memimpin juga menggambarkan pendekatan yang digunakannya dalam mempengaruh anggotanya, baik menggunakan orientasi tugas untuk mencapai produktivitas tinggi, maupun orientasi hubungan manusia dengan memperhatikan hubungan baik dengan anggotanya.

Ada empat perilaku kepemimpinan:

1. Memerintah (directive), yaitu pimpinan memberitahu apa dan kapan sesuatu dikerjakan pegawai, tidak ada partisipasi dalam pengambilan keputusan;

2. Mendukung (Supportive), yaitu pimpinan menjadi sahabat bagi pegawai dan menunjukkan minat kepada mereka;

3. Memudahkan (Fasilitative), yaitu pimpinan memberitahu sasaran dan melibatkan pegawai dalam pengambila keputusan; dan

\footnotetext{
${ }^{2}$ Herman Sofyandi , Manajemen Sumber Daya, (Yogyakarta : Graha Ilmu : 2008), hlm. 179

${ }^{3}$ H.M. Daryanto, Administrasi dan Manajemen sekolah, ( Jakarta: Rineka Cipta, 2013, hlm.

${ }^{4}$ Onisimus Amtu , Manajemen Pendidikan di Era Otonomi Daerah, (Bandung: Alfabeta,2013):, hlm 52
} 
4. Orientasi Prestasi (Achievement-Oriented), yaitu pimpinan mmebagi sumbagan tujuan dan menunjukkan kepercayaan bahwa pegawai mampu mencapainya. ${ }^{5}$.

Selain perilaku di atas, seorang perilaku pimpinan juga mempunyai karakteristik : 1. perangai (menyenangkan, periang, rileks, menarik); 2. semangat (bersemangat, hangat); 3. keterbukaan (menerima, -terbuka); 4. kesejawatan (bersahabat, dekat); 5. dipercaya (percaya diri, membantu, mendukung); dan 6. kerjasama (kerjasama, harmonis, efisien).

Pemimpin yang ideal untuk lembaga pendidikan adalah yang memiliki sifat - sifat sebagai berikut:

1. Capacity, meliputi: a. kecerdasan, b. kewaspadaan, c. kemampuan bicara, d. keterampilan, e. kemampuan nilai.

2. Achievement, meliputi: a. gelar kesarjaan, b. pengetahuan, c. keberhasilan, d. kesehatan jasmani.

3. Responsibility, meliputi: a. mandiri dan berinisiatif, b. tekun, c. agresif, d. percaya diri , e. futuristic

4. Participation, meliputi: a. aktif, b. relationship, c. pandai membangun team works, d. adaptif

5. Situation, meliputi: mental yang baik, b. status, c. skill, d. energik, e. fleksibel, f. good oriented. 6

Pada setiap jurusan terdapat seorang Ketua Jurusan dan Sekretaris jurusan serta beberapa orang dosen ditambah dengan beberapa orang personel jurusan lainnya sesuai dengan kebutuhan jurusan tersebut. Keberhasilan Jurusan menjalankan misinya sangat bergantung kepada semua pihak yang terlibat di dalamnya. Agar personel Jurusan dapat berfungsi sebagaimana mestinya, mutlak adanya hubungan yang baik dan harmonis di antara sesama personel yaitu hubungan baik antara Ketua Jurusan dengan Dosen, pegawai dan mahasiswa .

Kepemimpinan Ketua Jurusan memegang peranan penting dalam kemajuan jurusan. Jiwa kepemimpinan Ketua Jurusan dipertaruhkan dalam proses pembinaan para dosen, mahasiswa dan pegawai. Sebagai pemimpin ia harus mengetahui, mengerti dan memahami semua hal yang berkaiatan dengan

\footnotetext{
${ }^{5}$ Syafaruddin,dkk. Kepemimpinan dan Kewirausahaan, ( Medan : Perdana Publishing, 2010), hlm. hlm. 47-48

${ }^{6}$ Hikmat, Manajemen pendidikan, ( Bandung: Pustaka Setia, 2009), hlm.261-262
} 
40 | TAZKIR: Jurnal Penelitian Ilmu-ilmu Sosial dan Keislaman

Vol. 02 No. 2 Desember 2016

administrasi jurusan. Bahkan, ia harus memahami potensi yang dimiliki oleh mahasiswa, pegawai dan dosennya, sehingga komunikasi dengan para dosen, mahasiswa dan pegawai akan membantu kinerjanya, terutama untuk menyelesaikan masalah yang dihadapi oleh jurusan yang dipimpinnya. Dalam melaksanakan kepemimpinanya Ketua Jurusan harus memberikan saran balikan kepada bawahan. Saran dan balikan dari pimpinan sangat penting bagi bawahan. Cara pemimpin dalam mmeberikan umpan balik atas keberhasilan dan kegagalan anggotanya adalah sebagai berikut:

1. Diam. Bila Pemimpin tidak memberikan respon terhadap kerja anggota timnya,

2. Kritik. Ketika mencoba untuk menghentikan perilaku atau hasil yang tidak diinginkan, pemimpin mungkin mengkritik anggota.

3. Saran. Ketika memberitahu bawahan mengenai apa yang harus dilakukan dan hasil seperti apa yang diinginkan, kepercayaan dan hubungan dengn mereka akan membaik. Hal ini dapat mendorong peningkatan kinerja akan hasilnya

4. Penguatan positif. Umpan balik merupakan salah satu langkah yang lebih jauh dari pimpinan untuk mengidentifikasi berapa banyak akan menghargai bantuan anggota dalam mencapai perilaku atau hasil yang diinginkan. ${ }^{7}$

\section{METODOLOGI PENELITIAN}

Penelitian ini dilakukan pada Institut Agama Islam Negeri Padangsidimpuan yang beralamat di jalan H. Tengku Rizal Nurdin KM. 4,5 Sihitang, Padangsidimpuan Tenggara. Penelitian ini dilaksanakan pada tahun 2015. Penelitian ini menggunakan metode deskriptif kuantitatif. “Metode deskriptif adalah metode penelitian yang bertujuan mendeskripsikan sesuatu atau menjelaskan sesuatu hal seperti apa adanya dan memungkinkan peneliti memilih salah satu objek penelitian untuk dikaji secara mendalam" ${ }^{\prime 8}$. Informan yang akan dijadikan sumber data primer dalam penelitian ini adalah Dosen, Mahasiswa dan pegawai yang ada di Fakultas Tarbiyah dan Ilmu Keguruan Jurusan Pendidikan Agama Islam, Tadris Matematika, Tadris Bahasa Inggris dan Pendidikan Bahasa Arab. Informan yang akan dijadikan sumber data sekunder dalam penelitian ini adalah dosen tidak tetap yang ada di Fakultas Tarbiyah dan

\footnotetext{
7 Sudarwan Danim, Kepemimpinan Pendidikan ( Kepemimpinan Jenius ( IQ + EQ) , Etika Perilaku Motivasional, dan Mitos), ( Bandung: Alfabeta, 2010), hlm.31

${ }^{8}$ Prasetya Irawan, Logika dan Prosedur Penelitian (Jakarta: STIA LAN, 1999), hlm. 60
} 
Ilmu Keguruan. Adapun Instrumen Pengumpulan Data adalah Observasi, Wawancara dan angket. Penelitian ini menggunakan pendekatan kuantitatif deskriptif, penelitian ini membutuhkan data dalam bentuk interval, maka data akan dianalisis dengan pendekatan kuantitatif dengan bantuan statistik sebagai alat untuk pengolahan data.

\section{HASIL PENELITIAN DAN PEMBAHASAN}

Hasil dan pembahasan dari penelitian ini akan dideskripsikan secara jelas dalam paparan berikut ini.

Persepsi dosen tentang perilaku kepemimpinan Ketua- Ketua Jurusan di Lingkungan Fakultas Tarbiyah dan Ilmu Keguruan IAIN Padangsidimpuan

1. Persepsi Dosen terhadap Ketua Jurusan Pendidikan Agama Islam

Pemimpin adalah seorang yang memiliki kecakapan tertentu yang dapat mempengaruhi para pengikutnya untuk melakukan kerja sama ke arah pencapaian tujuan yang telah ditetapkan. Data yang diperoleh dengan melihat indikator perilaku kepemimpinan yang sudah ditentukan, yaitu menampilkan diri sebagai pribadi yang taqwa dan berakhlak mulia, teladan bagi peserta didik dan masyarakat, dari sisi Perangai (menyenangkan, menarik), dapat dilihat dari tabel berikut ini:

Tabel 1

Angket Persepsi Dosen tentang perilaku kepemimpinan Ketua Jurusan PAI

\begin{tabular}{lcccccccc}
\hline $\begin{array}{l}\text { NO. } \\
\text { Angket }\end{array}$ & \multicolumn{2}{l}{ Sangat Setuju } & Setuju & & Tidak Setuju & \multicolumn{2}{l}{$\begin{array}{l}\text { Sangat } \\
\text { Tidak } \\
\text { Setuju }\end{array}$} \\
\hline & & & & & & & & \\
\hline & F & $\%$ & F & $\%$ & F & $\%$ & F & $\%$ \\
\hline 1 & 6 & $60 \%$ & 4 & $40 \%$ & - & - & - & - \\
\hline 3 & 6 & $60 \%$ & 4 & $40 \%$ & - & - & - & - \\
\hline 4 & 2 & $20 \%$ & 8 & $80 \%$ & - & - & - & - \\
\hline 5 & 5 & $50 \%$ & 5 & $50 \%$ & - & - & - & - \\
\hline 6 & 5 & $50 \%$ & 3 & $30 \%$ & 2 & $20 \%$ & - & - \\
\hline 7 & 5 & $50 \%$ & 4 & $40 \%$ & 1 & $10 \%$ & - & - \\
\hline 8 & 3 & $30 \%$ & 7 & $70 \%$ & - & - & - & - \\
\hline 9 & 2 & $20 \%$ & 6 & $60 \%$ & 1 & $10 \%$ & 1 & $10 \%$ \\
\hline
\end{tabular}


42 | TAZKIR: Jurnal Penelitian Ilmu-ilmu Sosial dan Keislaman

Vol. 02 No. 2 Desember 2016

\begin{tabular}{lcccccccc}
\hline $\begin{array}{l}\text { NO. } \\
\text { Angket }\end{array}$ & Sangat Setuju & Setuju & & Tidak Setuju & \multicolumn{2}{l}{$\begin{array}{l}\text { Sangat } \\
\text { Tidak } \\
\text { Setuju }\end{array}$} \\
\hline 10 & 1 & $10 \%$ & 8 & $80 \%$ & - & - & 1 & $10 \%$ \\
\hline 11 & - & - & 7 & $70 \%$ & 2 & $20 \%$ & 1 & $10 \%$ \\
\hline 12 & - & - & 6 & $60 \%$ & 3 & $30 \%$ & 1 & $10 \%$ \\
\hline 13 & 1 & $10 \%$ & 8 & $80 \%$ & 1 & - & - & \\
\hline 14 & 2 & $20 \%$ & 6 & $60 \%$ & 2 & $20 \%$ & - & \\
\hline 15 & 1 & $10 \%$ & 5 & $50 \%$ & 3 & $30 \%$ & 1 & $10 \%$ \\
\hline
\end{tabular}

Dari hasil angket di atas dapat dibaca bahwa pada umumnya dosen PAI sangat setuju dan setuju bahwa Ketua Jurusan PAI alumni IAIN Padangsidimpuan mempunyai prilaku kepemimpinan yang baik, beriman bertaqwa, bisa jadi teladan, namun dalam mengontrol perkuliahan Ketua Jurusan PAI masih kurang demikian juga dalam memotivasi dosen untuk melaksanakan penelitian Ketua Jurusan PAI belum begitu perhatian.

Hal ini sejalan dengan hasil wawancara yang disampaikan salah satu dosen PAI: " Akhlak Ketua Jurusan PAI sudah bagus, bisa jadi teladan, tapi manajemennya kurang, kurang kreatif dan kurang inovatif". ${ }^{9}$ Tingkat persepsi dosen terhadap kepemimpinan Ketua Jurusan PAI masuk karegori "baik", yaitu 77\% dari skor ideal

\section{Persepsi Dosen terhadap Ketua Jurusan Tadris / Pendidikan Matematika}

Persepsi Dosen Tadris / pendidikan Matematika terhadap kepemimpinan Ketua Jurusan TMM dapat dilihat dari Data yang diperoleh dari hasil angket yang telah disebarkan kepada responden sebagai berikut:

Tabel 2

Angket Persepsi Dosen tentang perilaku kepemimpinan Ketua Jurusan TMM

\begin{tabular}{lcccccccc}
\hline $\begin{array}{l}\text { NO. } \\
\text { Angket }\end{array}$ & Sangat Setuju & Setuju & \multicolumn{2}{c}{$\begin{array}{l}\text { Tidak } \\
\text { Setuju }\end{array}$} & \multicolumn{2}{c}{$\begin{array}{l}\text { Sangat Tidak } \\
\text { Setuju }\end{array}$} \\
\hline & $\mathrm{F}$ & $\%$ & $\mathrm{~F}$ & $\%$ & $\mathrm{~F}$ & $\%$ & $\mathrm{~F}$ & $\%$ \\
\hline 1 & 5 & $50 \%$ & 5 & $50 \%$ & - & - & - & - \\
\hline
\end{tabular}

${ }^{9}$ Asnah. Dosen dan Sekretaris Lembaga Penjaminan Mutu, . Wawancara tanggal 30 Oktober 2015 


\begin{tabular}{lllllllll}
\hline 2 & 4 & $40 \%$ & 6 & $60 \%$ & - & - & - & - \\
\hline 3 & 3 & $30 \%$ & 7 & $70 \%$ & - & - & - & - \\
\hline 4 & 3 & $30 \%$ & 7 & $70 \%$ & - & - & - & - \\
\hline 5 & 3 & $30 \%$ & 7 & $70 \%$ & - & - & - & - \\
\hline 6 & 1 & $10 \%$ & 9 & 90 & - & - & - & - \\
\hline 7 & 6 & $60 \%$ & 4 & $40 \%$ & - & - & - & - \\
\hline 8 & 4 & $40 \%$ & 6 & $60 \%$ & - & - & - & - \\
\hline 9 & 4 & $40 \%$ & 6 & $60 \%$ & - & - & - & - \\
\hline 10 & 5 & $50 \%$ & 5 & $50 \%$ & - & - & - & - \\
\hline 11 & 1 & $10 \%$ & 9 & $90 \%$ & - & - & - & - \\
\hline 13 & 3 & $30 \%$ & 7 & $70 \%$ & - & - & - & - \\
\hline 14 & 2 & $20 \%$ & 8 & $80 \%$ & - & - & - & - \\
\hline 15 & 2 & $20 \%$ & 8 & $80 \%$ & - & - & - & - \\
\hline
\end{tabular}

Dari hasil angket di atas dapat dibaca bahwa pada umumnya dosen TMM setuju bahwa Ketua Jurusan TMM mempunyai perilaku kepemimpinan yang baik untuk dapat diteladani. Persepsi dosen terhadap kepemimpinan Ketua Jurusan Tadris / Pendidikan Matematika adalah baik yaitu $82,5 \%$ dari skor ideal.

\section{Persepsi Dosen Tadris / Pendidikan Bahasa Inggris terhadap Ketua Jurusan}

Persepsi Dosen Tadris / pendidikan Bahasa Inggris terhadap kepemimpinan Ketua Jurusan TBI dapat dilihat dari Data yang diperoleh dari hasil angket yang telah disebarkan kepada responden sebagaimana tabel berikut:

Tabel 3

Angket Persepsi Dosen tentang perilaku kepemimpinan Ketua Jurusan TBI

\begin{tabular}{lcccccccc}
\hline $\begin{array}{l}\text { NO. } \\
\text { Angket }\end{array}$ & Sangat Setuju & Setuju & & Tidak Setuju $\begin{array}{l}\text { Sangat } \\
\text { Tidak } \\
\text { Setuju }\end{array}$ \\
\hline & & & & & & & & \\
\hline & F & $\%$ & F & $\%$ & F & $\%$ & F & $\%$ \\
\hline 1 & 4 & $40 \%$ & 6 & $60 \%$ & - & - & - & - \\
\hline 2 & 5 & $50 \%$ & 5 & $50 \%$ & - & - & - & - \\
\hline 3 & 4 & $40 \%$ & 6 & $60 \%$ & - & - & - & - \\
\hline 4 & 5 & $50 \%$ & 5 & $50 \%$ & - & - & - & - \\
\hline 5 & 3 & $30 \%$ & 7 & $70 \%$ & - & - & - & - \\
\hline
\end{tabular}


44 | TAZKIR: Jurnal Penelitian Ilmu-ilmu Sosial dan Keislaman

Vol.02 No. 2 Desember 2016

\begin{tabular}{lllllllll}
\hline 6 & 4 & $40 \%$ & 6 & $60 \%$ & - & - & - & - \\
\hline 7 & 4 & $40 \%$ & 4 & $40 \%$ & 2 & $20 \%$ & - & - \\
\hline 8 & 5 & $50 \%$ & 5 & $50 \%$ & - & - & - & - \\
\hline 9 & 3 & $30 \%$ & 7 & $70 \%$ & - & - & - & - \\
\hline 10 & 3 & $30 \%$ & 7 & $70 \%$ & - & - & - & - \\
\hline 11 & 3 & $30 \%$ & 7 & $70 \%$ & - & - & - & - \\
\hline 12 & 2 & $20 \%$ & 5 & $50 \%$ & 3 & $30 \%$ & - & - \\
\hline 13 & 2 & $20 \%$ & 8 & $80 \%$ & - & - & - & - \\
\hline 14 & 2 & $20 \%$ & 8 & $80 \%$ & - & - & - & - \\
\hline 15 & 5 & $50 \%$ & 5 & $50 \%$ & - & - & - & - \\
\hline
\end{tabular}

Dari Hasil Angket di atas dapat dibaca bahwa pada umumnya dosen setuju bahwa Ketua Jurusan TBI mempunyai perilaku kepemimpinan yang baik untuk dapat diteladani, mempunyai akhlak namun dalam memotivasi dosen - dosen untuk melaksanakan penelitian masih kurang.

Hal ini di dukung hasil wawancara dengan salah satu dosen menyatakan: " Kajur TBI mempunyai akhlak yang baik, beliau kreatif, inovatif dan menyelesaikan tugas yang dibebankan."10Selain itu dosen yang lain menyebutkan: "Kajur TBI menampilkan diri sebagai pribadi yang bertaqwa, berakhlak mulia. Hal ini terlihat dari sikap dan tindak tanduk Kajur dalam keseharian serta ibadah yang dilakukan.Dalam hal keteladanan diri Kajur cukup bisa menjadi suri tauladan dalam hal akhlak dan tindakan. Dalam hal tanggap terhadap permasalahan Kajur agak sedikit kurang perhatian, hal ini disebabkan karena kajur tidak dapat mengambil kebijakan dan kebijaksanaan sendiri, karena semua harus sesuai prosedur serta segala sesuatunya harus mendapatkan izin dan restu dari pimpinan ( dekan atau wakil dekan). Dalam memanajemen Kajur cukup baik dalam memberikan instruksi dan membagi tugas, kerjasama kelompok cukup bagus terbangun, dan dapat memberikan feedback dengan baik pada bawahan baik itu dosen maupun administrasi. ${ }^{11}$ Tingkat persepsi dosen terhadap kepemimpinan Ketua Jurusan Tadris / Pendidikan Bahasa Inggris masuk karegori "baik", yaitu $83,16 \%$ dari skor ideal.

${ }^{10}$ Asnah. Dosen dan Sekretaris Penjaminan Mutu, Wawancara tanggal 30 Oktober 2015

11 Eka Sustri Harida, Dosen Tadris / Pendidikan Bahasa Inggris, Wawancara Tanggal 1 Nopember 2015. 


\section{Persepsi Dosen Pendidikan Bahasa Arab terhadap Ketua Jurusan}

Persepsi Dosen Pendidikan Bahasa Arab terhadap kepemimpinan Ketua Jurusan PBA dapat dilihat dari Data yang diperoleh dari hasil angket yang telah disebarkan kepada responden sebagaimana tabel berikut:

Tabel 4

Angket Persepsi Dosen tentang perilaku kepemimpinan Ketua Jurusan PBA

\begin{tabular}{|c|c|c|c|c|c|c|c|c|}
\hline \multirow[t]{2}{*}{$\begin{array}{l}\text { NO. } \\
\text { Angket }\end{array}$} & Sang & Setuju & \multicolumn{2}{|c|}{ Setuju } & Tida & Setuju & \multicolumn{2}{|c|}{$\begin{array}{l}\text { Sangat } \\
\text { Tidak } \\
\text { Setuju }\end{array}$} \\
\hline & $\mathrm{F}$ & $\%$ & $\mathrm{~F}$ & $\%$ & $\mathrm{~F}$ & $\%$ & $\mathrm{~F}$ & $\%$ \\
\hline 1 & 5 & $50 \%$ & 5 & $50 \%$ & - & - & - & - \\
\hline 2 & 4 & $40 \%$ & 6 & $60 \%$ & - & - & - & - \\
\hline 3 & 4 & $40 \%$ & 6 & $60 \%$ & - & - & - & - \\
\hline 4 & 3 & $30 \%$ & 7 & $70 \%$ & - & - & - & - \\
\hline 5 & 4 & $40 \%$ & 6 & $60 \%$ & - & - & - & - \\
\hline 6 & 4 & $40 \%$ & 6 & $60 \%$ & - & - & - & - \\
\hline 7 & 4 & $40 \%$ & 6 & $60 \%$ & - & - & - & - \\
\hline 8 & 4 & $40 \%$ & 6 & $60 \%$ & - & - & - & - \\
\hline 9 & 4 & $40 \%$ & 6 & $60 \%$ & - & - & - & - \\
\hline 10 & 3 & $30 \%$ & 7 & $70 \%$ & - & - & - & - \\
\hline 11 & 4 & $40 \%$ & 6 & $60 \%$ & - & - & - & - \\
\hline 12 & - & - & 8 & $80 \%$ & 2 & $20 \%$ & - & - \\
\hline 13 & 3 & $30 \%$ & 7 & $70 \%$ & - & - & - & - \\
\hline 14 & 3 & $30 \%$ & 7 & $70 \%$ & - & - & - & - \\
\hline 15 & 2 & $20 \%$ & 8 & $80 \%$ & - & - & - & - \\
\hline
\end{tabular}

Dari Hasil Angket di atas dapat dibaca bahwa pada umumnya dosen PBA sangat setuju dan setuju bahwa Ketua Jurusan PBA mempunyai perilaku kepemimpinan yang baik untuk dapat diteladani, namun dalam mendorong dosen - dosen untuk melaksanakan penelitian masih kurang. Sehingga dapat disimpulkan bahwa tingkat persepsi dosen terhadap kepemimpinan Ketua Jurusan Pendidikan Bahasa Arab masuk karegori “baik”, yaitu 83,5 \% dari skor ideal. 
46 | TAZKIR: Jurnal Penelitian Ilmu-ilmu Sosial dan Keislaman

Vol.02 No. 2 Desember 2016

Persepsi Mahasiswa tentang perilaku kepemimpinan Ketua - Ketua Jurusan di Lingkungan Fakultas Tarbiyah dan Ilmu Keguruan IAIN Padangsidimpuan 1. Persepsi Mahasiswa Pendidikan Agama Islam

Mahasiswa adalah salah satu faktor yang terpenting dalam suatu perguruan tinggi, tanpa kehadiran mahasiswa maka perguruan tinggi tidak ada artinya. Persepsi Mahasiswa Pendidikan Agama Islam terhadap kepemimpinan Ketua Jurusan PAI dapat dilihat dari Data yang diperoleh dari hasil angket yang telah disebarkan kepada 100 responden sebagaimana tabel berikut:

Tabel 5

Persepsi Mahasiswa tentang perilaku kepemimpinan Ketua Jurusan

Pendidikan Agama Islam

\begin{tabular}{lcccccccc}
\hline $\begin{array}{l}\text { NO. } \\
\text { Angket }\end{array}$ & Sangat Setuju & Setuju & & Tidak Setuju & \multicolumn{2}{l}{$\begin{array}{l}\text { Sangat } \\
\text { Tidak } \\
\text { Setuju }\end{array}$} \\
\hline & & & & & & & & \\
\hline 1 & F & $\%$ & F & $\%$ & F & $\%$ & F & $\%$ \\
\hline 2 & 53 & $53 \%$ & 46 & $46 \%$ & 1 & $1 \%$ & - & - \\
\hline 3 & 38 & $38 \%$ & 60 & $60 \%$ & 1 & $1 \%$ & $1 \%$ & $1 \%$ \\
\hline 4 & 27 & $27 \%$ & 71 & $71 \%$ & 2 & $2 \%$ & - & - \\
\hline 5 & 10 & $10 \%$ & 75 & $75 \%$ & 15 & $15 \%$ & - & - \\
\hline 6 & 16 & $16 \%$ & 63 & $63 \%$ & 21 & $21 \%$ & - & - \\
\hline 7 & 23 & $23 \%$ & 60 & $60 \%$ & 17 & $17 \%$ & - & - \\
\hline 8 & 29 & $29 \%$ & 59 & $59 \%$ & 10 & $10 \%$ & 2 & $2 \%$ \\
\hline 9 & 24 & $24 \%$ & 59 & $59 \%$ & 10 & $10 \%$ & 7 & $7 \%$ \\
\hline 10 & 27 & $27 \%$ & 59 & $59 \%$ & 14 & $14 \%$ & - & - \\
\hline 11 & 29 & $29 \%$ & 62 & $62 \%$ & 5 & $5 \%$ & 4 & $4 \%$ \\
\hline 12 & 37 & $37 \%$ & 56 & $56 \%$ & 6 & $6 \%$ & 1 & $1 \%$ \\
\hline 13 & 35 & $35 \%$ & 59 & $59 \%$ & 5 & $5 \%$ & 1 & $1 \%$ \\
\hline 14 & 25 & $25 \%$ & 69 & $69 \%$ & 5 & $5 \%$ & 1 & $\% 1$ \\
\hline 15 & 22 & $22 \%$ & 63 & $63 \%$ & 14 & $14 \%$ & 1 & $1 \%$ \\
\hline & 44 & $44 \%$ & 44 & $44 \%$ & 11 & $11 \%$ & 1 & $1 \%$ \\
\hline
\end{tabular}

Dari Hasil Angket di atas dapat dibaca bahwa pada umumnya mahasiswa PAI setuju bahwa Ketua Jurusan PAI mempunyai perilaku kepemimpinan yang baik untuk dapat diteladani. 
Tingkat persepsi mahasiswa terhadap kepemimpinan Ketua Jurusan Pendidikan agama Islam masuk karegori "baik", yaitu 79,48 \% dari skor ideal.

Hal ini sejalan dengan pernyataan mahasiswa Jurusan Pendidikan Agma Islam “ Bapak Ketua Jurusan PAI bisa menampilkan diri sebagai pribadi yang taqwa hal ini saya nilai dari kesibukannya sehari - hari di kampus, bagaimanapun sibuknya beliau, tetap mengerjakan sholat ketika masuk waktu walaupun hanya sholat dikantornya, dan beliau saya lihat berakhlak mulia dan dapat dijadikan teladan oleh peserta didik. Beliau juga tanggap terhadap masalah mahasiswa, kalau ada mahasiswa yang bermasalah beliau memberi jalan keluarnya.Beliau juga sering memotivasi dan menasehati mahasiswa dalam hal apa saja terutama urusan akademik"12

\section{Persepsi Mahasiswa Tadris / Pendidikan Matematika}

Persepsi Mahasiswa Tadris / Pendidikan Matematika terhadap kepemimpinan Ketua Jurusan TMM dapat dilihat dari Data yang diperoleh dari hasil angket yang telah disebarkan kepada 50 responden sebagaimana tabel berikut:

\section{Tabel 6}

Persepsi Mahasiswa tentang perilaku kepemimpinan Ketua Jurusan Tadris / Pendidikan Matematika

\begin{tabular}{lcccccccc}
\hline $\begin{array}{l}\text { NO. } \\
\text { Angket }\end{array}$ & \multicolumn{1}{l}{ Sangat Setuju } & Setuju & & Tidak Setuju $\begin{array}{l}\text { Sangat } \\
\text { Tidak } \\
\text { Setuju }\end{array}$ \\
\hline & & & & & & & \multicolumn{3}{l}{${ }^{2}$} \\
\hline 1 & $\mathrm{~F}$ & $\%$ & $\mathrm{~F}$ & $\%$ & $\mathrm{~F}$ & $\%$ & $\mathrm{~F}$ & $\%$ \\
\hline 2 & 5 & $10 \%$ & 44 & $88 \%$ & 1 & $2 \%$ & - & \\
\hline 3 & 4 & $8 \%$ & 38 & $76 \%$ & 8 & $16 \%$ & & \\
\hline 4 & 3 & $6 \%$ & 41 & $82 \%$ & 6 & $12 \%$ & & \\
\hline 5 & 3 & $6 \%$ & 30 & $60 \%$ & 16 & $32 \%$ & 1 & $2 \%$ \\
\hline 6 & 5 & $10 \%$ & 27 & $54 \%$ & 17 & $34 \%$ & 1 & $2 \%$ \\
\hline 7 & 4 & $8 \%$ & 32 & $64 \%$ & 12 & $24 \%$ & 2 & $4 \%$ \\
\hline 8 & 6 & $12 \%$ & 32 & $64 \%$ & 11 & $22 \%$ & 1 & $2 \%$ \\
\hline 9 & 7 & $14 \%$ & 34 & $68 \%$ & 9 & $18 \%$ & & \\
\hline
\end{tabular}

${ }^{12}$ Nurainun. Mahasiswa Jurusan Pendidikan Agama Islam., Wawancara tanggal 26 Oktober 2015 
48 | TAZKIR: Jurnal Penelitian Ilmu-ilmu Sosial dan Keislaman

Vol. 02 No. 2 Desember 2016

\begin{tabular}{lcccccccc}
\hline 10 & 8 & $16 \%$ & 36 & $72 \%$ & 5 & $10 \%$ & 1 & $2 \%$ \\
\hline 11 & 5 & $10 \%$ & 37 & $74 \%$ & 8 & $16 \%$ & - & \\
\hline 12 & 13 & $26 \%$ & 29 & $58 \%$ & 7 & $14 \%$ & 1 & $2 \%$ \\
\hline 13 & 8 & $16 \%$ & 36 & $72 \%$ & 6 & $! 2 \%$ & - & \\
\hline 14 & 6 & $12 \%$ & 29 & $58 \%$ & 15 & $30 \%$ & - & \\
\hline 15 & 13 & $25 \%$ & 29 & $58 \%$ & 6 & $12 \%$ & 2 & $4 \%$ \\
\hline
\end{tabular}

Dari Hasil Angket di atas dapat dibaca bahwa pada umumnya mahasiswa TMM setuju bahwa Ketua Jurusan TMM mempunyai perilaku kepemimpinan yang baik untuk dapat diteladani, namun Ketua Jurusan bukan pribadi yang ceria dan hangat,

Hal ini sejalan dengan ungkapan salah satu mahasiswa TMM yang akan menyelesaikan studinya: " Ketua jurusan kurang tanggap terhadap permasalahan yang dihadapi mahasiswa sehingga mahasiswa banyak yang mengeluh, dan memotivasi mahasiswa dalam kegiatan belajar kurang, kadang beranggapan bahwa kemampuan mahasiswa itu dibuat seperti diri bapak itu." 13

Tingkat persepsi mahasiswa terhadap kepemimpinan Ketua Jurusan Tadris / Pendidikan Matematika masuk karegori “cukup atau sedang sedang saja ", yaitu 72,93\% dari skor ideal.

\section{Persepsi Mahasiswa Tadris / Pendidikan Bahasa Inggris}

Persepsi Mahasiswa Tadris / Pendidikan Bahasa Inggris terhadap kepemimpinan Ketua Jurusan TBI dapat dilihat dari Data yang diperoleh dari hasil angket yang telah disebarkan kepada 50 responden sebagaimana tabel berikut:

Tabel 7

Persepsi Mahasiswa tentang perilaku kepemimpinan Ketua Jurusan Tadris / Pendidikan Bahasa Inggris

\begin{tabular}{|l|c|c|c|l|c|c|c|c|}
\hline $\begin{array}{l}\text { NO. } \\
\text { Angket }\end{array}$ & \multicolumn{2}{|l|}{ Sangat Setuju } & \multicolumn{2}{l|}{ Setuju } & \multicolumn{3}{l|}{ Tidak Setuju } & \multicolumn{2}{l|}{$\begin{array}{l}\text { Sangat Tidak } \\
\text { Setuju }\end{array}$} \\
\hline & F & $\%$ & F & $\%$ & F & $\%$ & F & $\%$ \\
\hline 1 & 26 & $52 \%$ & 23 & $46 \%$ & 1 & $2 \%$ & & \\
\hline 2 & 16 & $32 \%$ & 34 & $68 \%$ & & & & \\
\hline
\end{tabular}

${ }^{13}$ Wafida. MahasiswaJurusan Tadris / Pendidikan Matematika. Wawancara tanggal 2 November 2015 


\begin{tabular}{|l|c|c|c|c|c|c|l|l|}
\hline $\begin{array}{l}\text { NO. } \\
\text { Angket }\end{array}$ & \multicolumn{3}{|l|}{ Sangat Setuju } & \multicolumn{3}{l|}{ Setuju } & \multicolumn{3}{l|}{ Tidak Setuju } & \multicolumn{2}{l|}{$\begin{array}{l}\text { Sangat Tidak } \\
\text { Setuju }\end{array}$} \\
\hline 3 & 24 & $48 \%$ & 25 & $50 \%$ & 1 & $2 \%$ & & \\
\hline 4 & 14 & $28 \%$ & 31 & $62 \%$ & 5 & $10 \%$ & & \\
\hline 5 & 17 & $34 \%$ & 30 & $60 \%$ & 3 & $6 \%$ & & \\
\hline 6 & 14 & $28 \%$ & 32 & $64 \%$ & 4 & $8 \%$ & & \\
\hline 7 & 11 & $22 \%$ & 31 & $62 \%$ & 8 & $16 \%$ & & \\
\hline 8 & 13 & $26 \%$ & 32 & $64 \%$ & 5 & $10 \%$ & & \\
\hline 9 & 10 & $20 \%$ & 31 & $62 \%$ & 9 & $18 \%$ & & \\
\hline 10 & 17 & $34 \%$ & 31 & $62 \%$ & 2 & $4 \%$ & & \\
\hline 11 & 21 & $42 \%$ & 26 & $52 \%$ & 3 & $6 \%$ & & \\
\hline 12 & 15 & $30 \%$ & 29 & $58 \%$ & 6 & $12 \%$ & & \\
\hline 13 & 13 & $26 \%$ & 33 & $66 \%$ & 4 & $8 \%$ & & \\
\hline 14 & 22 & $44 \%$ & 26 & $52 \%$ & 2 & $4 \%$ & & \\
\hline 15 & 23 & $46 \%$ & 24 & $48 \%$ & 3 & $6 \%$ & & \\
\hline
\end{tabular}

Dari Hasil Angket di atas dapat dibaca bahwa pada umumnya mahasiswa TBI sangat setuju dan setuju bahwa Ketua Jurusan TBI mempunyai perilaku kepemimpinan yang baik untuk dapat diteladani.

Hal ini sejalan dengan pernyataan mahasiswa TBI:" Ketua Jurusan Tadris / Pendidikan Bahasa Inggris memiliki akhlak yang sangat baik, ini ditunjukkan dari cara beliau menyapa mahasiswa, melayani urusan di kantor jurusan. Beliau tidak pernah menunjukkan akhlak yang tidak terpuji, dan menjadi teladan tidak hanya bagi mahasiwa, tapi semua yang berinteraksi dengan beliau. Beliau juga memiliki kepribadian yang menyenangkan seperti ramah dan mudah tersenyum.Meski begitu, beliau juga orang yang mempunyai integritas saat menegakkan disiplin di lingkungan kantornya". ${ }^{14}$

Tingkat persepsi mahasiswa terhadap kepemimpinan Ketua Jurusan Tadris / Pendidikan Bahasa Inggris masuk karegori “baik”, yaitu 81,7\% dari skor ideal. 
50 | TAZKIR: Jurnal Penelitian Ilmu-ilmu Sosial dan Keislaman

Vol. 02 No. 2 Desember 2016

\section{Persepsi Mahasiswa Jurusan Pendidikan Bahasa Arab}

Persepsi Mahasiswa terhadap kepemimpinan Ketua Jurusan Pendidikan Bahasa Arab dapat dilihat dari Data yang diperoleh dari hasil angket yang telah disebarkan kepada 32 responden sebagaimana tabel berikut:

Tabel 8.

Persepsi Mahasiswa tentang perilaku kepemimpinan Ketua Jurusan Pendidikan Bahasa Arab

\begin{tabular}{|c|c|c|c|c|c|c|c|c|}
\hline \multirow[t]{2}{*}{$\begin{array}{l}\text { NO. } \\
\text { Angket }\end{array}$} & \multicolumn{2}{|c|}{ Sangat Setuju } & \multicolumn{2}{|c|}{ Setuju } & \multicolumn{2}{|c|}{ Tidak Setuju } & \multicolumn{2}{|c|}{$\begin{array}{l}\text { Sangat Tidak } \\
\text { Setuju }\end{array}$} \\
\hline & $\mathrm{F}$ & $\%$ & $\mathrm{~F}$ & $\%$ & $\mathrm{~F}$ & $\%$ & $\mathrm{~F}$ & $\%$ \\
\hline 1 & 22 & $68,8 \%$ & 9 & $28,1 \%$ & 1 & $3,1 \%$ & - & - \\
\hline 2 & 10 & $31,25 \%$ & 22 & $68,8 \%$ & - & - & - & - \\
\hline 3 & 9 & $28,1 \%$ & 21 & $65,76 \%$ & 1 & $3,1 \%$ & 1 & $3,1 \%$ \\
\hline 4 & 3 & $9,38 \%$ & 7 & $21,87 \%$ & 22 & $68,8 \%$ & 1 & $3,1 \%$ \\
\hline 5 & 19 & $59,37 \%$ & 3 & $9,38 \%$ & 10 & $31,25 \%$ & - & - \\
\hline 6 & 5 & $15,63 \%$ & 20 & $62,5 \%$ & 7 & $21,87 \%$ & - & - \\
\hline 7 & 22 & $68,8 \%$ & 7 & $21,87 \%$ & 3 & $9,38 \%$ & - & - \\
\hline 8 & 16 & $50 \%$ & 14 & $43,75 \%$ & 2 & $6,25 \%$ & - & - \\
\hline 9 & 14 & $43,75 \%$ & 17 & $53,15 \%$ & - & - & 1 & $3,1 \%$ \\
\hline 10 & 16 & $50 \%$ & 15 & $46,9 \%$ & 1 & $3,1 \%$ & - & - \\
\hline 11 & 25 & $78,12 \%$ & 5 & $15,63 \%$ & 2 &, $25 \%$ & - & - \\
\hline 12 & 18 & $56,25 \%$ & 11 & $34,375 \%$ & 3 & $9,38 \%$ & - & - \\
\hline 13 & 21 & $65,76 \%$ & 9 & $28,1 \%$ & 2 & $25 \%$ & - & - \\
\hline 14 & 11 & & 15 & $46,9 \%$ & 6 & $18,75 \%$ & 1 & $3,1 \%$ \\
\hline 15 & 19 & $59,37 \%$ & 12 & - & 1 & $3,1 \%$ & - & - \\
\hline
\end{tabular}

Dari Hasil Angket di atas dapat dibaca bahwa pada umumnya mahasiswa PBA setuju bahwa Ketua Jurusan PBA mempunyai perilaku kepemimpinan yang baik untuk dapat diteladani.

Tingkat persepsi mahasiswa terhadap kepemimpinan Ketua Jurusan Pendidikan Bahasa Arab masuk karegori "baik”, yaitu 84,63 \% dari skor ideal. 


\section{Persepsi Pegawai tentang perilaku kepemimpinan Ketua - Ketua Jurusan di Lingkungan Fakultas Tarbiyah dan Ilmu Keguruan IAIN Padangsidimpuan}

Pegawai merupakan salah satu unsur yang berperan dalam kegiatan administrasi di perguruan tinggi. Pegawai dalam menjalankan pekerjaannya tidak sekedar hanya sebagai pengikut dari apa yang diinstruksikan pemimpin, melainkan juga penentu keberhasilan suatu lembaga dalam mencapai tujuan organisasi. Persepsi Pegawai tentang perilaku pemimpin akan mempengaruhi kinerjanya. Pemimpin harus mampu memberikan instruksi / perintah dan membagi tugas kepada bawahan, mampu membangun kerjasama kelompok, mampu memotivasi bawahan, mampu memberikan feedback secara tegas, dan mampu mengendalikan bawahan.

Pada umumnya pegawai menyatakan bahwa para Kajur di lingkungan Fakultas Tarbiyah dan Ilmu Keguruan adalah orang - orang yang bertaqwa dan berakhlak mulia, bisa jadi teladan bagi anak didiknya, bisa membangun kerjasama yang baik, memberi masukan dan bimbingan kepada bawahan, namun masih kurang dalam memberikan dorongan kepada bawahan untuk dapat mengembangkan diri secara profesional.

Dari hasil observasi yang telah dilakukan peneliti juga terlihat para kajur di lingkungan Fakultas Tarbiyah dan Ilmu Keguruan adalah orang - orang taat beribadah, mereka selalu mengerjakan shalat ketika masuk waktu sholat, semangat bekerja dan menyelesaikan tugas - tugas yang dibebankan secara baik.

Salah satu pegawai mengungkapkan "Akhlak Ketua Jurusan PAI memberikan teladan kepada staf dan mahasiswanya, menjalankan perintah Allah dan menjauhi laranganNya, bersemangat dalam bekerja dan menyenangkan walaupun sedikit terkadang ada kelalaian mungkin factor usia dan banyaknya aktivitas, beliau tanggap terhadap permasalahan, rajin memotivasi staf dan mahasiswanya apabila kurang bersemangat."15

Demikian juga dengan kajur yang lain menurut salah satu staf bahwa" Ketua Jurusan Tadris / Pendidikan Matematika mampu menampilkan diri sebagai pribadi yang taqwa dan berakhlak mulia, teladan bagi peserta didik, memiliki etos kerja yang perlu ditingkatkan" ${ }^{\prime \prime}$.

${ }^{15}$ Mahadir Muhammad, Staf di FTIK, wawancara Tanggal 3 Nopember 2015

${ }^{16}$ Sofiah , Staf di FTIK, Wawancara Tanggal 5 Nopember 2015 
52 | TAZKIR: Jurnal Penelitian Ilmu-ilmu Sosial dan Keislaman

Vol. 02 No. 2 Desember 2016

\section{Pembahasan Hasil Penelitian}

Temuan Dalam penelitian ini menunjukkan bahwa persepsi dosen atas kepemimpinan Ketua - Ketua Jurusan di lingkungan IAIN Padangsidimpuan adalah baik. Mereka memandang bahwa perilaku Ketua - Ketua Jurusan adalah baik dan dapat diteladani, namun dalam mendorong dosen - dosen untuk melaksanakan penelitian masih kurang. Hal ini tentunya suatu yang harus di perbaiki. Penelitian merupakan bahagian dari Tri dharma perguruan tinggi, maka dosen - dosen harus di dorong untuk melaksanakan penelitian, baik secara individual maupun kelompok, dengan biaya dari pemerintah ataupun biaya sendiri.

Adapun persepsi mahasiswa terhadap kepemimpinan Ketua - Ketua Jurusan adalah baik untuk prodi PAI, TBI dan PBA sedangkan untuk Ketua Jurusan TMM sedang - sedang saja. Pada umumnya akhlak Ketua Jurusan baik dan bisa jadi contoh, menunjukkan etos kerja dan bertanggung jawb terhadap tugas, namun dalam berurusan di jurusan sebahagian mahasiswa masih merasa takut. Dalam melayani mahasiswa seharusnya Ketua Jurusan melaksanakannya dengan sebaik-baiknya, jangan ada image bahwa berurusan di Jurusan sangat sulit, Ketua Jurusan hendaknya menerima dan menanggapi setiap permasalahan mahasiswa dengan tangan terbuka.

Sama dengan persepsi dosen, pegawai di lingkungan Fakultas Tarbiyah dan Ilmu Keguruan juga memandang Ketua - Ketua jurusan adalah orang orang yang bertaqwa dan berakhlak mulia, bisa membangun kerjasama yang baik, memberi masukan dan bimbingan kepada bawahan , namun masih kurang dalam memberikan dorongan kepada bawahan untuk dapat mengembangkan diri secara profesional.

\section{PENUTUP}

Berdasarkan hasil penelitian yang dilakukan, dapat ditarik kesimpulan bahwa : Persepsi dosen, mahasiswa dan pegawai tentang perilaku kepemimpinan ketua - ketua Jurusan di Lingkungan Fakultas Tarbiyah dan Ilmu Keguruan IAIN adalah baik. 


\section{DAFTAR RUJUKAN}

Herman Sofyandi, Manajemen Sumber Daya, Yogyakarta : Graha Ilmu : 2008

Hikmat, Manajemen pendidikan, Bandung: Pustaka Setia, 2009

H.M. Daryanto, Administrasi dan Manajemen sekolah, Jakarta: Rineka Cipta, 2013.

Onisimus Amtu, Manajemen Pendidikan di Era Otonomi Daerah, Bandung: Alfabeta,2013

Prasetya Irawan, Logika dan Prosedur Penelitian , Jakarta: STIA LAN, 1999.

Sudarwan Danim, Kepemimpinan Pendidikan, Kepemimpinan Jenius ( $I Q+E Q)$, Etika, Perilaku Motivasional, dan Mitos), Bandung: Alfabeta, 2010

Syafaruddin,dkk. Kepemimpinan dan Kewirausahaan, Medan : Perdana Publishing, 2010

Sekolah Tinggi Agama Islam Negeri Padangsidimpuan. Standar Mutu Mahasiswa, Padangsidimpuan: STAIN Psp, 2013 
54 | TAZKIR: Jurnal Penelitian Ilmu-ilmu Sosial dan Keislaman

Vol. 02 No. 2 Desember 2016

Peningkatan Aktivitas Pendidikan Keberagamaanistri Pegawai Negeri Sipil Melalui Arisan pada Kegiatan Rutinitas Bulanan di Dharma Wanita Persatuan IAIN Padangsidimpuan 